Journal of

Women's Health and Gynecology

\title{
Antenatal Psychosocial Assessment and Depression Screening: What Are the Views of Women Delivering in The Private Sector?
}

\section{Tanya Connell ${ }^{*}$}

Sydney university, Australia

${ }^{*}$ Corresponding author: Tanya Connell, 5 Bayline Drive, Point Clare. 2250, Sydney university, Australia, Tel: +041-297-0347, E-mail: Tanya_connell@bigpond.com

Received Date: April 12, 2019 Accepted Date: May 20, 2019 Published Date: May 22, 2019

Citation: Tanya Connell (2019) Views of Women Delivering in The Private Sector? J Womens Health Gyn 6: 1-6.

\begin{abstract}
Psychosocial assessment including depression screening has been established and in fact mandated [2] in the public maternity sector in various states of Australia [3,4] The private sector has not established the same mandate. Researchers have sought the views of the women screened in the public sector and the majority report favourable feedback [8]. Women have rarely been similarly assessed in the private sector. Never the less, relevant programs are now being trialled [7]. During follow-up phone calls from the researcher to the study participants, the comments described here were made. Two hundred and fifty-five women were screened at their antenatal visit. They were followed up postnatally, however 40 women were lost to follow up. The majority viewed the process favourably; however, some women gave specific feedback.
\end{abstract}

Keywords: Psychosocial screening, women's views of psychosocial screening, perinatal mental health 


\section{Introduction}

Perinatal psychosocial screening is well established as best practice to enable service providers to identify risk factors and current mental health issues and offer support and referral in a timely manner $[10,2,1]$ Never the less, implementation of perinatal psychosocial screening and assessment across service providers remains uneven [6].

\section{Aims of the Study}

In this study the researcher sought opinions regarding their personal psychosocial screening experience from women in one small regional private hospital in NSW.

\section{Method}

This aspect was part of a wider study: "Psychosocial assessment and depression screening in private obstetric care". The women $(n=215)$ were followed up by telephone postpartum. Discussion included using the EPDS [5] and they were invited to comment on their experience and opinions regarding their antenatal session. A total of four groups of participants were recruited during the implementation phase of the wider study. Apart from the 255 women participants (Group 1) described here, booking-in midwives (Group 2) and obstetricians, midwives and other health professionals employed by the regional private hospital study site (Group 3) were recruited to semi-structured qualitative interviews to explore barriers to Guideline implementation during the Phase 3 implementation study.

\section{Results}

Two hundred and fifty-five women were contacted and 209 were followed up postpartum. Forty women were lost to follow up for various reasons (uncontactable, did not have time, not interested). During the follow-up telephone interview, the 209 women agreeing to continue with the study had the opportunity to expand upon their EPDS responses. Specifically, they were asked about their experience of booking-in to the private hospital study site, about their experiences at the hospital and of motherhood more generally. The women were also asked about their experience of the psychosocial risk questionnaire conducted during the booking-in visit and were offered as much time as they needed to comment. Women were also recommended additional supports if a psychosocial need or risk was identified during this conversation. Nine women offered the following comments (Table 6.8) during the telephone conversation and of these, seven had total EPDS scores greater than 10 (3.3\%). Their postnatal EPDS profile is also given, as is the researcher's response to their comment. The remaining participants had no further comment. As above, Question 10 of the EPDS (The thought of harming myself has occurred to me) [5] can be answered 'yes quite often' (score of 3); 'sometimes' (2); 'hardly ever' (1); or 'never' (0) [5].

\section{Various Negative Themes Emerged in the Follow-Up, Namely}

- Disappointment with the booking-in screening process

- Feeling let down by obstetricians

- The personal nature of the psychosocial questions

Of all the participants in the study 15 women (7.2\%) had either a total postnatal EPDS score above nine (indicating some level of risk for perinatal depression) or had expressed concerns during the follow-up phone call. Many women were grateful for the psychosocial screening process, but some women expressed concern. This study sought to represent the concerns of women about the screening process. The three emerging themes need to be considered when screening women for psychosocial risk factors and current possible illness.

\section{Disappointment with The Booking-In Screening Pro- cess}

Some women felt disappointment with the booking-in screening process, and the failure to identify obvious issues and ensure referral." Why didn't someone talk to me antenatally. I am a nurse, my husband is a DR. I knew that I was depressed during the pregnancy and no one did anything or told me anything. I went and saw my GP myself”.

\section{Feeling Let Down by Obstetricians}

Some women indicated that they were disappointed with obstetric care from private obstetricians and a lack of recognition of issues. "I was completely let down by the hospital and my OB". This is echoed in literature in the public sector [9]. 


\begin{tabular}{|c|c|}
\hline EPDS refusal & Researcher response and comments \\
\hline $\begin{array}{l}\text { "My baby is now } 10.5 \text { months old. The study was sup- } \\
\text { posed to be } 6 \text { weeks after birth. I was completely let down } \\
\text { by the hospital and my OB } \\
\text { (obstetrician). I don't want to take part in any of your } \\
\text { studies. Please take me off your database." }\end{array}$ & $\begin{array}{l}\text { Researcher: "I am sorry to hear that. Can I help? I } \\
\text { have left several messages previously with no reply. } \\
\text { I'm happy to chat if you wish." } \\
\text { Participant Response: "No I'm fine thanks." }\end{array}$ \\
\hline $\begin{array}{l}\text { Text message received: "I do not want follow-up. I found } \\
\text { the questions extremely personal and unexpected and } \\
\text { they were not asked sensitively. I spoke with my OB re- } \\
\text { garding this as I was upset following the questionnaire. } \\
\text { Thanks for following up though." }\end{array}$ & $\begin{array}{l}\text { Researcher (by text): "I am sorry to hear that. By } \\
\text { the way I did not ask the questions at booking-in. } \\
\text { I only do follow-up's after the baby is born. Thank } \\
\text { you for your feedback. If you would like to give me } \\
\text { more feedback, I'm happy to listen. I am interested } \\
\text { to know any problems with the screening to sug- } \\
\text { gest changes to improve." } \\
\text { No response from participant. }\end{array}$ \\
\hline $\begin{array}{l}\text { "I've been working with my GP and getting the help I } \\
\text { need from them. Thank you for following up." }\end{array}$ & Researcher: "Thank you for participating." \\
\hline $\begin{array}{l}\text { Husband answered: Wife in hospital post stroke and } \\
\text { does not want follow-up }\end{array}$ & $\begin{array}{l}\text { Researcher: "I'm so sorry to hear that, thank you for } \\
\text { participating." }\end{array}$ \\
\hline Text message received: "I'm too busy" & \\
\hline $\begin{array}{l}\text { "Why didn't someone talk to me antenatally? I am a } \\
\text { nurse, my husband is a Dr. I knew that I was depressed } \\
\text { during the pregnancy and no one did anything or told } \\
\text { me anything. I went and saw my GP myself." }\end{array}$ & $\begin{array}{l}\text { Researcher: "I'm so sorry you did not receive the } \\
\text { support you needed. It's great that you went to see } \\
\text { your GP for help." }\end{array}$ \\
\hline
\end{tabular}

Table 1. Reasons for follow-up refusal 


\begin{tabular}{|c|c|}
\hline $\begin{array}{l}\text { Participant EPDS follow-up score } \\
\text { and comment }\end{array}$ & Researcher actions and comments \\
\hline $\begin{array}{l}\text { EPDS total score }=16 \text { (potential high } \\
\text { risk) } \\
\text { Question } 10 \text { score }=1\end{array}$ & $\begin{array}{l}\text { Researcher: Referred to a psychologist and rang one week later to } \\
\text { check on her, but-no answer. } \\
\text { Text received: "Thank you, yes I'm contacting the counsellor". }\end{array}$ \\
\hline $\begin{array}{l}\text { EPDS total score }=15 \text { (potential high } \\
\text { risk) } \\
\text { Question } 10 \text { score }=0\end{array}$ & $\begin{array}{l}\text { Researcher: Rang one week later with no response. Sent a text mes- } \\
\text { sage: "This is Tanya the midwife from the private hospital doing } \\
\text { the study. I hope that you are doing OK. I am passing the phone } \\
\text { number on to you for the counsellor. } \\
\text { Best wishes". Second text message: R U doing OK? } \\
\text { No response }\end{array}$ \\
\hline $\begin{array}{l}\text { EPDS total score }=20 \text { (potential } \\
\text { high risk/of concern) Question } 10 \\
\text { score }=0\end{array}$ & $\begin{array}{l}\text { Researcher: Referred to a psychologist. Rang back in one week. } \\
\text { Text received "Thankyou I have been seeing a therapist and am on } \\
\text { medication and feel much better now, thanks for caring". }\end{array}$ \\
\hline $\begin{array}{l}\text { EPDS total score }=16 \text { (potential high } \\
\text { risk) } \\
\text { Question } 10 \text { score }=0 \\
\text { Seeing a psychologist, history of post- } \\
\text { natal depression (PND), good sup- } \\
\text { ports. }\end{array}$ & $\begin{array}{l}\text { Researcher: Encouraged her proactive approach by seeing a psychol- } \\
\text { ogist already. }\end{array}$ \\
\hline $\begin{array}{l}\text { EPDS total score }=14 \text { (potential high } \\
\text { risk) } \\
\text { Question } 10 \text { score }=2 \\
\text { Seeing a psychologist and has joined } \\
\text { a PND group. }\end{array}$ & $\begin{array}{l}\text { Researcher: Encouraged her proactive approach by seeing a psy- } \\
\text { chologist already. Had no self-harm plan, this was discussed and } \\
\text { further encouraged to discuss with psychologist. }\end{array}$ \\
\hline $\begin{array}{l}\text { EPDS total score }=12 \text { (potential me- } \\
\text { dium risk) } \\
\text { Question } 10 \text { score }=0 \\
\text { EPDS results discussed }\end{array}$ & Researcher: Recommended a GP/counsellor \\
\hline $\begin{array}{l}\text { EPDS total score }=20 \text { (potential } \\
\text { high risk/of concern) Question } 10 \\
\text { score }=0 \\
\text { Has seen a psychiatrist previously }\end{array}$ & $\begin{array}{l}\text { Researcher: Encouraged her to follow up again with psychiatrist - } \\
\text { she will call them today. }\end{array}$ \\
\hline $\begin{array}{l}\text { EPDS total score }=8 \\
\text { (low risk) } \\
\text { Question } 10 \text { score }=0 \text { History } \\
\text { of PND and sees a psychologist }\end{array}$ & $\begin{array}{l}\text { Researcher: Encouraged her proactive approach by seeing a psychol- } \\
\text { ogist already. }\end{array}$ \\
\hline $\begin{array}{l}\text { EPDS total score }=9 \\
\text { (low risk) } \\
\text { Question } 10 \text { score }=0 \\
\text { Sounded stressed and anxious }\end{array}$ & $\begin{array}{l}\text { Researcher: Recommended ATAPS (Access To Allied } \\
\text { Psychological Services) counselling through the GP. She said that } \\
\text { she would see her GP and 'follow-up' }\end{array}$ \\
\hline
\end{tabular}

Table 2. EPDS follow-up comments and referral actions 
The Personal Nature of the Psychosocial Screening Questions

Some women were concerned about the personal nature of the psychosocial screening questions: "I found the questions extremely personal and unexpected and they were not asked sensitively".

\section{Relevance of Findings/Contribution to the Literature}

This study supports that wider literature in that the majority of women reported that the screening experience was acceptable and not upsetting [8]. However, preparing women for screening is also important. Women indicate that they would like a 'pre-warning' of the sensitive nature of the booking-in questions so that they know what to expect (Table.1) [8]. Strategies for ongoing care must emphasise that utilising support and accessing services is inherent in perinatal care.

\section{Discussion}

The postnatal EPDS was conducted by asking the mother to respond to the questions over the telephone with 209 of the 255 (82\%) participants completing follow-up. Forty-six women were lost to follow-up for various reasons. Six of the original 255 women $(2.3 \%)$ reached by telephone refused to continue in the study and the remaining 40 (15.6\%) were uncontactable. Women were contacted up to five times by phone and messages were left with return telephone details before participants were categorised as 'lost to follow-up'. Difficulty contacting women during the postnatal period is clearly an important factor and acts a barrier to completion of perinatal screening. The six participants refusing any further follow-up responded by text message or in person over the telephone. Their comments are included below in (Table 6.7). For at least one woman who chose not to continue with the study, the screening process had failed to identify her mental health needs or trigger an appropriate referral. The Table also outlines the researcher's response to their comments. During the follow-up telephone interview, the 209 women agreeing to continue with the study had the opportunity to expand upon their EPDS responses. Specifically, they were asked about their experience of booking-in to the private hospital study site, about their experiences at the hospital and of motherhood more generally. The women were also asked about their experience of the psychosocial risk questionnaire conducted during the booking-in visit and were offered as much time as they needed to comment. Women were also recommended additional sup- ports if a psychosocial need or risk was identified during this conversation. Nine women offered the following comments (Table 6.8) during the telephone conversation and of these, seven had total EPDS scores greater than 10 (3.3\%). Their postnatal EPDS profile is also given, as is the researcher's response to their comment. The remaining participants had no further comment. As above, Question 10 of the EPDS (The thought of harming myself has occurred to me) [5] can be answered 'yes quite often' (score of 3); 'sometimes' (2); 'hardly ever' (1); or 'never' (0) [5].

\section{Strengths of the study}

A large number of women (255) participated in the study and were followed up (215 women).

\section{Limitations of the study}

Views were gathered from one cohort of women only, therefore may not be generalisable to the whole population. $\mathrm{Pa}$ tients were recruited as part of the wider study antenatally and followed up post-partum. They were therefore not randomly selected. Nevertheless, the feedback from the women must be taken into account when implementing such programs. Further training of all relevant staff and monitoring of the process are essential. 


\section{References}

1. Austin, M. P., Highet, N., \& the Expert Working Group. (2017) Mental Health Care in the Perinatal Period: Australian Clinical Practice Guideline Melbourne: Centre of Perinatal Excellence.

2. Australian Government Department of Health. (2009) Framework for the national perinatal depression initiative 2008-09 to 2012-13.

3. Beyond blue. (2008a) Beyond blue Perinatal Mental Health National Action plan, 2008-2011.

4. Beyond blue. (2008b) the national depressive initiative mental health national action plan 2008-2010 full report. perinatal mental health consortium.

5. Cox, J. L., Holden, J. M., \& Sagovsky, R. (1987) Detection of postnatal depression. Development of the 10-item Edinburgh Postnatal Depression Scale. British Journal of Psychiatry, 150,782-786.

6. Fisher, Chatham, Haseler, McGaw, \& Thompson. (2012) Uneven implementation of the National Perinatal Depression Initiative: findings from a survey of Australian women's hospitals. Australian \& New Zealand Journal of Obstetrics \& Gynaecology, 6:559-564.

7. Kohlhoff, J., Hickinbottom, R., Knox, C., Roach, V., \& Barnett, B. (2016) Antenatal psychosocial assessment and depression screening in a private hospital. Australian \& New Zealand Journal of Obstetrics \& Gynaecology, 56, 173-178.

8. $\quad$ Matthey, S., White, T., Phillips, J., Taouk, R., Chee, T. T., \& Barnett, B. (2005) Acceptability of routine antenatal psychosocial assessments to women from English and non-English speaking backgrounds. Archives of Women's Mental Health, 3:171-180

9. Rollans, M., Schmied, V., Kemp, L., \& Meade, T. (2013) Digging over that old ground: an Australian perspective of women's experience of psychosocial assessment and depression screening in pregnancy and following birth. BMC Women's Health, 13:18.

10. Society, M. I. (2013) Position Statement 2013: Psychosocial assessment and depression screening in perinatal women.
Submit your manuscript to a JScholar journal and benefit from:

๑ Convenient online submission

ฯ Rigorous peer review

I Immediate publication on acceptance

- Open access: articles freely available online

ฯ High visibility within the field

ब Better discount for your subsequent articles

Submit your manuscript at

http://www.jscholaronline.org/submit-manuscript.php 